Bul. Agrohorti 4(2): 155-164 (2016)

\title{
Aplikasi Biomulsa Arachis pintoi Krap. \& Greg. terhadap Kualitas Tanah dan Produksi Sayuran pada Dua Musim Tanam
}

\author{
Application of Arachis pintoi Krap. \& Greg. as Biomulch toward Soil Quality and Vegetables Production \\ in Two Plant Season
}

\author{
Muhammad Isnan* dan Juang Gema Kartika*
}

Departemen Agronomi dan Hortikultura, Fakultas Pertanian, Institut Pertanian Bogor (Bogor Agricultural University), Jl. Meranti, Kampus IPB Darmaga, Bogor 16680, Indonesia Telp. \& Faks.62-251-8629353 e-mail agronipb@indo.net.id

*Penulis korespondensi: ika_juang@yahoo.com

Disetujui 4 Mei 2016/ Published online 9 Mei 2016

\begin{abstract}
This research was conducted in Leuwikopo Experimental Field-IPB, Darmaga Bogor from August to December 2013. The objective of this research was to evaluate the effect of biomulch aplication in Pinto Peanut (Arachis pintoi) in order to increase growth and production of angled loofah (Luffa acutangula) and pakchoi (Brassica chinensis) and its effect to soil quality. The research done in two experiment in a series at same area. In first season the area planting angled loffa and than in second season planting pak-choi without soil processing but do replacing plastic mulch to pakchoi planting. Types of mulch are consisted of no mulch, plastic mulch, and Arachis pintoi biomulch. The results research shows that the treatment of A. pinto biomulch in two season have the repair soil quality with add value of $C$-organic more than other treatments. Treatment of mulch in angled loofah have affect to vegetatif growing with the best value at plastic mulch and in A. pintoi biomulch have lower value. In production component A. pintoi biomulch have low value diffirence of no mulch and plastic mulch have higher and in high. Generaly plastic mulch treatment have the best value more than no mulch and A. pintoi biomulch to hight plan, total of leaf, weight of root, and weight of harvest.
\end{abstract}

Keywords: angled loofah, Arachis pintoi, biomulch, pakchoi, soil quality

\section{ABSTRAK}

Penelitian ini dilaksanakan di Kebun Percobaan Leuwikopo IPB, Darmaga Bogor dari bulan Agustus hingga Desember 2013. Tujuan penelitian ini untuk mengevaluasi pengaruh aplikasi biomulsa Arachis pintoi dalam peningkatkan pertumbuhan dan produksi tanaman oyong (Luffa acutangula) dan pakcoy (Brassica chinensis) serta dampaknya terhadap kualitas tanah. Penelitian ini terdiri dari dua percobaan yang dilakukan secara berurutan menggunakan bedeng yang sama. Musim tanam petama bedeng ditanam tanaman oyong, sedangkan musim tanam kedua dengan tanaman pakcoy tanpa pengolahan tanah namun dilakukan penggantian mulsa plastik hitam perak (MPHP) sesuai jarak tanam pakcoy. Perlakuan terdiri atas tanpa mulsa, mulsa plastik hitam perak, biomulsa Arachis pintoi. Hasil penelitian menunjukkan bahwa penggunaan biomulsa Arachis pintoi setelah dua musim tanam menunjukan penurunan nilai $C$ organik paling kecil dibandingkan perlakuan lain. Perlakuan MPHP pada tanaman oyong meningkatkan pertumbuhan vegetatif yaitu pada parameter panjang tanaman, jumlah cabang dan bobot brangkasan dengan respon yang sama dengan perlakuan tanpa mulsa, sedangkan pada parameter bobot akar perlakuan MPHP memiliki nilai paling tinggi dari perlakuan lainnya. Perlakuan MPHP terhadap komponen produksi buah/tanaman dan jumlah buah/tanaman memiliki respon yang paling baik dibandingkan perlakuan lainnya. Secara umum perlakuan MPHP memiliki nilai terbaik dibandingkan dengan perlakuan tanpa mulsa dan biomulsa A. pintoi terhadap tinggi tanaman, jumlah daun, bobot akar, dan bobot panen.

Kata kunci: Arachis pintoi, biomulsa, kualitas tanah, oyong, pakcoy 


\section{PENDAHULUAN}

Pengembangan subsektor hortikultura merupakan bagian yang tidak terpisahkan dari upaya, pelestarian lingkungan, penciptaan lingkungan asri, penciptaan lapangan kerja dan peningkatan pendapatan, menarik investasi skala kecil dan menengah, pengendalian inflasi dan stabilisasi harga komoditas strategis (cabai merah dan bawang merah), pelestarian dan pengembangan identitas nasional (anggrek, jamu, dll), peningkatan ketahanan pangan melalui penyediaan karbohidrat alternatif, dan penunjang pengembangan sektor pariwisata (Deptan, 2013). Untuk itu perlu adanya usaha dalam memperbaiki teknik budidaya pertanian sesuai kebijakan pemerintah.

Peningkatan jumlah penduduk akan menyebabkan semakin meningkatkan konsumsi sayuran. Sayuran sendiri termasuk sumber gizi yang diperlukan masyarakat. Jenis sayuran yang ada di Indonesia antara lain jenis kubis-kubisan (Brassicaceae) dan labu-labuan (Cucurbitaceae) termasuk didalamnya pakcoy dan oyong.

Kacang hias (Arachis pintoi) merupakan tanaman tahunan golongan kacang-kacangan (leguminoceae) yang tumbuh menjalar di atas permukaan tanah. Kacang hias ini tumbuh baik di daerah tropis, baik di dataran rendah maupun dataran tinggi (Balittan, 2004). Persyaratan penting yang harus dimiliki tanaman penutup tanah adalah mudah diperbanyak, mempunyai sistem perakaran yang tidak mengganggu tanaman pokok, pertumbuhannya cepat, tahan pangkas, dan dapat memfiksasi $\mathrm{N}$ bebas. Tanaman ini memiliki potensi dalam menambat nitrogen dari udara. Berdasarkan sifat-sifat tersebut, $A$. pintoi sangat baik ditanam sebagai biomulsa pada produksi sayuran dan buah, tanaman penutup tanah, bahan hijauan makanan ternak, ataupun sebagai tanaman hias (Kartika et al., 2009).

Jenis mulsa yang banyak digunakan selama ini adalah mulsa plastik hitam perak, mulsa plastik transparan, plastik hitam, dan mulsa perak. Penggunaan mulsa jenis plastik dilihat dari cara aplikasinya cukup mudah namun secara kimia tidak berpengaruh pada kesuburan tanah karena sulit lapuk dan secara ekonomi harganya cukup mahal. Residu dari penggunaan mulsa yang hanya terpakai untuk sekali tanam juga menjadi kelemahan dari penggunaan mulsa sehingga perlu untuk mencari jenis mulsa lain yang lebih efektif.

A. pintoi sebagai mulsa diharapkan mampu menyumbang hara untuk kesuburan tanah. Mulsa jenis kacang hias ini juga lebih mudah ditumbuhkan dan dikembangkan sehingga tidak membutuhkan biaya investasi untuk pembelian mulsa setiap awal tanam. Selain itu diharapkan dengan penggunaan mulsa kacang hias ini dapat memperbaiki kualitas tanah untuk meningkatkan produksi tanaman sayuran. Penelitian ini bertujuan untuk mempelajari pengaruh aplikasi biomulsa kacang dalam pertumbuhan dan produksi tanaman oyong (Luffa acutangula) dan pakcoy (Brassica chinensis) serta dampaknya terhadap kualitas tanah selama dua musim tanam.

\section{BAHAN DAN METODE}

Penelitian dilakukan di kebun percobaan Leuwikopo, Fakultas Pertanian IPB, Dramaga, Bogor. Pelaksanaan penelitian lapang dilakukan pada bulan Agustus sampai Desember tahun 2013. Penanaman oyong pada bulan Agustus hingga Oktober, sedangkan penanaman pakcoy pada bulan Desember. Analisis tanah dilakukan di Laboratorium Tanah, Departemen Manajemen Sumberdaya Lahan, Institut Pertanian Bogor.

Bahan tanaman yang digunakan dalam penelitian ini adalah benih sayuran oyong (Luffa acutangula) varietas Pagoda F1 dan pakcoy (Brassica chinensis) varietas Nauli F1. Bahan mulsa yang dipakai adalah mulsa plastik hitam perak dan bahan rumpun A. pintoi. Bahan lain yang digunakan adalah pupuk kandang, pupuk NPK mutiara, Gandasil D, insektisida Decis 2.5 EC, dan insektisida Furadan 3G. Peralatan yang digunakan adalah tray semai; alat-alat pertanian; alat ukur; serta alat-alat lainnya yang menunjang pelaksanaan penelitian.

Penelitian ini terdiri dari dua percobaan atau dua musim tanam yang dilakukan secara berurutan. Musim tanam pertama dengan penanaman oyong kemudian musim tanam kedua dengan pakcoy. Jenis mulsa terdiri atas tiga jenis mulsa yaitu mulsa plastik hitam perak (MPHP), tanpa mulsa, dan biomulsa $A$. pintoi. Setiap perlakuan dibagi menjadi tiga petak yang pada setiap bedeng dan diambil 5 (lima) data untuk setiap petak.

Sebelum penanaman A. pintoi dilakukan pembersihan dan pengolahan lahan serta membuat bedengan untuk percobaan berukuran $23 \mathrm{~m}$ x 1.5 $\mathrm{m}$ termasuk jarak antar petak $30 \mathrm{~cm}$ tanpa jarak antar ulangan. Pemberian pupuk kandang dan kapur dilakukan setelah pembuatan bedengan. Kemudian dilakukan penanaman A. pintoi pada bedeng sesuai perlakuan. Biomulsa $A$. pintoi ditanam dalam bentuk rumpun dengan jarak tanam $25 \times 25 \mathrm{~cm}$. Penelitian ini dilaksanakan dalam dua musim yaitu tanaman oyong pada musim pertama dan pakcoy pada musim kedua. 
Jumlah tanaman oyong sebanyak 126 tanaman dan pakcoy sebanyak 513 tanaman.

Pengujian dilakukan saat sebelum tanam, saat panen musim pertama, dan saat selesai musim tanam kedua. Parameter yang diuji meliputi, kandungan nitrogen total dan karbon organik; $\mathrm{pH}$; dan EC (electrical conductivity).

\section{Musim Tanam I : Komoditas Oyong (Luffa acutangula)}

Penanaman oyong dilakukan pada bulan Agustus sampai bulan Oktober. Penanaman dilakukan pada petak ukuran $7.5 \mathrm{~m}$ x $1.5 \mathrm{~m}$ dengan jarak tanam $60 \mathrm{~cm} \times 100 \mathrm{~cm}$ dengan jumlah benih perlubang sebanyak satu benih. Penanaman dilakukan setelah 1 Minggu Setelah Tanam (MST) aplikasi biomulsa A. pintoi. Populasi oyong tiap unit percobaan sebanyak 13 sampai 14 tanaman dengan populasi total sebanyak 126 tanaman. Penanaman benih disertai dengan pemberian furadan. Saat penanaman dilakukan pula aplikasi pupuk kandang sebanyak 5 ton/ha pada lubang tanam. Pengendalian serangan hama dilakukan dengan penyemprotan insektisida jenis decis dengan dosis $2 \mathrm{cc} / \mathrm{l}$. Penyulaman pada tanaman yang tidak tumbuh atau mati dilakukan pada 14 hari setelah tanam (HST). Roguing dilakukan sekali seminggu dan penyiraman dilakukan setiap hari.

Pemasangan ajir dilakukan 3 (MST). Ajir dipasang tegak tepat di samping tanaman kemudian ditopang ajir lain yang terletak di tanah dekat dengan bedengan. Tanaman yang sudah menjalar kemudian dijalarkan ke ajir ini agar tumbuh keatas dengan penopang ajir.

Pemanenan dilakukan setelah 40 HST berdasarkan kriteria layak pasar yaitu saat buah telah berukuran sekitar $40 \mathrm{~cm}$ dan warna hijau muda. Pemanenen dilakukan dari mulai 40 HST sampai 75 HST sebanyak 7 kali panen. Panen didasarkan pengamatan visual jumlah buah siap panen berkisar 4 sampai 10 hari. Paramater yang diamati adalah panjang tanaman, jumlah cabang, bobot brangkasan, bobot akar dilakukan diakhir panen. Pengamatan lain berupa bobot buah/tanaman, panjang buah, jumlah buah/tanaman dan bobot/buah dilakukan setiap kali panen untuk kemudian diakumulasikan menjadi tolok ukur panen. Pengamatan kondisi tanah dilakukan di laboratorium departemen Ilmu Tanah dan Sumberdaya Lahan, Institut Pertanian Bogor.

Komponen hasil tanaman oyong diamati pada 5 (lima) tanaman contoh setiap petak perlakuan, peubah yang diamati adalah bobot buah/tanaman, bobot buah, jumlah buah/tanaman dan panjang buah. Pengamatan lain berupa bobot brangkasan, panjang tanaman, jumlah cabang dan bobot akar dilakukan diakhir panen.

\section{Musim Tanam II : Komoditas Pakcoy (Brassica chinensis)}

Benih pakcoy disemai di tray dengan jumlah lubang 128 lubang dengan satu benih untuk setiap lubang. Media semai menggunakan tanah dan kompos dengan perbandingan 2:1. Persemaian dipelihara sampai 14 hari. Pemeliharaan berupa penyiraman yang dilakukan setiap hari pada waktu menjelang siang. Penyulaman benih yang tidak tumbuh dilakukan pada hari ke-4.

Setelah 14 hari dipersemaian tanaman dipindah tanamkan ke lahan. Lahan yang digunakan adalah lahan bekas tanaman oyong tanpa pengolahan. Namun untuk mulsa plastik hitam perak dilakukan pergantian mulsa sesuai jarak tanam pakcoy. Lahan dibersihkan dari gulma kemudian dilakukan pemberian pupuk kandang dengan dosis 5 ton/ha kemudian dilakukan pemasangan mulsa dan dibuat lubang tanam dengan jarak $30 \mathrm{~cm}$ x $30 \mathrm{~cm}$. Penanaman satu bibit untuk setiap lubang tanam. Pemeliharaan dilakukan berupa penyiraman, pengendalian gulma diantara bedengan, dan pengendalian serangga. Tananam diberi pupuk daun Gandasil D pada hari ke-14 setelah pindah tanam dengan dosis $5 \mathrm{~kg} / \mathrm{ha}$ dengan cara disemprotkan dengan dosis sekitar $15 \mathrm{~g} / \mathrm{l}$.

Panen dilakukan pada 28 HST bersama akar tanaman. Pengamatan pertumbuhan berupa jumlah daun dan tinggi tanaman setiap 7 hari. Pengamatan panen dilakukan pada bobot panen/tanaman layak pasar dan bobot akar/tanaman.

\section{HASIL DAN PEMBAHASAN}

\section{Kondisi Umum}

Hasil analisis Laboratorium Departemen Ilmu Tanah dan Sumberdaya Lahan menunjukkan bahwa kondisi tanah awal penelitian mengandung C-organik (2.71\%), N-total (0.25\%), pH (6.00), EC $(51.90 \mu \mathrm{S} / \mathrm{cm})$, dan C/N (10.84). Berdasarkan kriteria penilaian sifat kimia tanah yang dikeluarkan oleh Pusat Penelitian Tanah (1983), kandungan $\mathrm{C}$-organik tanah dan $\mathrm{N}$-total tersebut tergolong sedang, $\mathrm{pH}$ agak masam, dan $\mathrm{C} / \mathrm{N}$ dan EC tergolong sedang.

Penanaman A. pintoi tidak mengalami kendala berarti karena cuaca dan lingkungan yang mendukung pertumbuhan. A pintoi menutupi 
keseluruhan bedeng pada 14 HST. Perkembangan A pintoi pada beberapa bagian terhambat karena adaptasi yang kurang baik namun kemudian kembali tumbuh dengan baik kemungkinan hal ini dikarenakan jumlah air yang kurang atau terlalu banyak. Pertumbuhan A. pintoi akan terhambat dan daun menjadi kuning pada tanah-tanah yang kurang air atau sering banjir (Balittan, 2004). Serangan hama tidak terlihat pada pertumbuhan $A$ pintoi begitu pula serangan penyakit.

Data curah hujan berkisar 258.3 sampai $503.2 \mathrm{~mm} /$ bulan musim tanam pertama yaitu tanaman oyong. Klasifikasi iklim ini menurut Oldeman termasuk bulan kering (BMKG, 2014). Pertumbuhan oyong cukup baik dengan daya berkecambah sebesar $88,8 \%$ pada umur 3 MST. Tanaman oyong tumbuh normal tanpa serangan penyakit yang terlihat selama fase vegetative, namun pada fase generatif mengalami serangan busuk buah dan lalat buah dalam jumlah yang sedikit. Hama yang menyerang tanaman terlihat dalam jumlah yang sedikit seperti belalang dan ulat. Serangan hama dikendalikan dengan penyemprotan decis dengan dosis 2cc/liter sebanyak dua kali selama penanaman. Menurut Puslitbanghorti (2013) organisme pengganggu tanaman (OPT) penting yang menyerang tanaman oyong antara lain kumbang daun, ulat grayak, ulat tanah, lalat buah, busuk daun, embun tepung, antraknosa, layu bakteri dan virus mosaik.

Data BMKG pada musim tanam kedua memiliki curah hujan sebesar $407.7 \mathrm{~mm} /$ tahun dengan klasifikasi Oldeman termasuk bulan basah (BMKG, 2014). Pertumbuhan awal tanaman pakcoy cukup baik dengan daya berkecambah persemaian $96,7 \%$ dan daya tumbuh setelah pindah tanam 86,3\%. Pertumbuhan tanaman pakcoy pada awal tanam terhambat oleh tingginya tajuk $A$. pintoi yang menutupi tanaman pakcoy sehingga perlu pembersihan piringan, namun pembersihan ini belum berkelanjutan sehingga tanaman masih tertekan pertumbuhannya. Serangan penyakit tidak terlihat sedangkan serangan hama belalang ada dalam jumlah kecil.

\section{Perubahan Kandungan Hara Tanah pada Perlakuan Mulsa}

Analisis tanah dilakukan sebanyak tiga kali yaitu sebelum perlakuan sebanyak satu sampel tanah, setelah musim pertama dan kedua masing-masing sebanyak tiga sampel tanah yang diambil dari setiap perlakuan. Pengambilan tanah dikedalaman sekitar $20 \mathrm{~cm}$ dengan satu sampel untuk satu perlakuan setelah musim pertama dan kedua secara acak dan diharapkan dapat mewakili kondisi kualitas tanah masing-masing perlakuan.

Tabel 1. Perbandingan analisis tanah sebelum perlakuan, setelah musim tanam pertama, dan setelah musim tanam kedua

\begin{tabular}{cccccccc}
\hline \multirow{2}{*}{ Komponen } & Kondisi awal & \multicolumn{3}{c}{ Musim Tanam I } & \multicolumn{3}{c}{ Musim Tanam II } \\
\cline { 2 - 7 } & $\mathrm{O}$ & MPHP & Tanpa mulsa & A. pintoi & MPHP & Tanpa mulsa & A. pintoi \\
\hline pH $\mathrm{H}_{2} \mathrm{O}$ & 6.00 & 6.20 & 6.40 & 6.20 & 6.20 & 5.90 & 6.10 \\
Walkley \& Black & & & & & & & \\
$\quad$ C-organik (\%) & 2.71 & 3.59 & 2.07 & 2.23 & 2.00 & 2.00 & 2.23 \\
Kjeldhal & & & & & & & \\
$\quad$ N-total $(\%)$ & 0.25 & 0.32 & 0.20 & 0.21 & 0.20 & 0.19 & 0.20 \\
EC $(\mu \mathrm{S} / \mathrm{cm})$ & 51.90 & 234.00 & 63.00 & 74.30 & 226.00 & 73.80 & 76.60 \\
$\mathrm{C} / \mathrm{N}$ & 10.84 & 11.22 & 10.35 & 10.63 & 10.00 & 10.53 & 11.15 \\
\hline
\end{tabular}

Keterangan: $\mathrm{MPHP}=$ mulsa plastik hitam perak, $\mathrm{O}=$ Kondisi awal.

\section{C-organik dan N-total. C-organik dan N-} total perlakuan MPHP setelah musim tanam pertama meningkat dibandingkan kondisi awal (Tabel 1). Hal ini diduga karena kondisi tanah yang terlindung dari cahaya matahari memberi kondisi inkubasi bahan organik dari penambahan pupuk kandang pada awal tanam. Sesuai penelitian Alfian (1997) bahwa lamanya inkubasi bahan organik dalam tanah mempengaruhi kadar $\mathrm{N}$-total tanah. Secara umum kadar N-total meningkat dengan bertambahnya waktu inkubasi. Kadar N-total tanah mencapai maksimum ratarata pada minggu ke-6 dan ke-7 setelah inkubasi. Kadar N-total tanah kemudian mendekati konstan, rata-rata pada 7 dan 9 minggu setelah inkubasi.
Perlakuan tanpa mulsa pada musim pertama memiliki nilai paling rendah untuk kandungan Corganik dan $\mathrm{N}$-total hal ini diduga karena terjadinya penguapan dan pencucian. Sedangkan pada perlakuan biomulsa $A$. pintoi penguapan dan pencucian dapat ditekan selain itu A. pintoi memberi sumbangan C-organik yang berasal dari serasah yang luruh. Armiadi (2009) menyebutkan kehilangan $\mathrm{N}$ di dalam tanah selain terjadi melalui pencucian dan diangkut oleh tanaman, juga terjadi melalui penguapan.

Pada musim tanam kedua relatif terjadi penurunan kandungan $\mathrm{C}$-organik dan $\mathrm{N}$-total pada semua perlakuan. Umur tanam musim kedua tanaman pakcoy hanya 4 MST diduga pengaruh 
pencucian dan penguapan tidak besar. Sedangkan penurunan nilai C-organik dan N-total yang lebih besar pada perlakuan MPHP karena terjadi penyerapan oleh tanaman yang besar dibanding perlakuan lainnya]. Menurut Boerhendhy dan Sianturi (1986) manfaat tanaman penutup tanah kacangan menghasilkan banyak bahan organik, mempunyai bintil akar (nodula) yang berfungsi untuk mengikat nitrogen bebas dari udara, menyerap unsur-unsur hara dari lapisan tanah yang lebih dalam, dan membantu mempercepat proses pembusukan bahan organik.

Kadar N-total tanah pada perlakuan biomulsa $A$. pintoi tidak terlihat perbedaan yang signifikan dari perlakuan lain. Karena $\mathrm{N}$ bebas diikat pada bintil akar dan dimanfaatkan oleh $A$. pintoi untuk pertumbuhannya. Sehingga tidak terlihat jumlah yang besar tertinggal ditanah dari hasil analisis yang dilakukan. McNeill et al. (1997) yang menggunakan teknik ${ }^{15} \mathrm{~N}$ diketahui bahwa $\mathrm{N}$ yang disumbangkan oleh bagian tanaman di bawah tanah cukup banyak yang berasal dari akar-akar halus, akar dan bintil akar yang terombak atau terkelupas serta eksudat akar.

Penggunaan biomulsa $A$. pintoi setelah dua musim tanam menunjukan penurunan nilai $\mathrm{C}$ organik yang paling kecil dibandingkan perlakuan lain. Hal ini karena tanaman A. pintoi menyumbang serasah yang terdekomposisi menjadi bahan organik tanah. Sehingga penggunaan $A$. pintoi baik untuk meningkatkan kandungan C-organik tanah. Kartasaputra \& Sutedjo (2000) menyatakan bahwa A. pintoi sebagai tanaman penutup tanah rendah yang pola penyebarannya horizontal, memiliki biomassa cukup tinggi yaitu berkisar antara 12-19 ton/ha per tahun bahan segar atau 3-6 ton/ha per tahun bahan kering. Hal ini secara fisik menguntungkan dibandingkan tanaman penutup lainnya. Tanaman ini mampu menghasilkan banyak bahan organik dan serasah yang berasal dari pelapukan daun dan batangnya.

Electrical Conductivity (EC). Electrical Conductivity (EC) atau daya hantar listrik (DHL) menunjukan jumlah ion-ion terlarut dalam larutan tanah yg dapat menghantarkan arus listrik. Nilai DHL para penanaman musim pertama dan kedua terjadi peningkatan pada semua perlakuan. Perlakuan tanpa mulsa memiliki nilai paling kecil (63.00 $\mu \mathrm{S} / \mathrm{cm})$ tidak berbeda jauh dengan perlakuan biomulsa A. pintoi $(74.30 \mu \mathrm{S} / \mathrm{cm})$ pada musim tanam pertama dan pada musim kedua. Nilai yang sangat jauh berbeda adalah perlakuan MPHP sekitar 3 kali lebih besar. Maka perlakuan MPHP paling baik untuk menyediakan ion-ion dalam tanah bagi pertumbuhan tanaman. Menurut
Effendi (2003) daya hantar listrik yang berkisar 20-1500 $\mu \mathrm{S} / \mathrm{cm}$ secara numerik menggambarkan kemampuan air dalam menghantarkan listrik melalui asam-asam, basa-basa, dan garam-garam bebas yang terlarut di dalamnya. Perlakuan MPHP memiliki nilai paling tinggi karena pada perlakuan MPHP tidak ada pencucian dan penguapan hara sebagaimana pembahasan pada nilai C-organik dan N-total.

Derajat keasaman . Perlakuan mulsa pada penanaman musim pertama secara umum meningkatkan $\mathrm{pH}$ tanah. Peningkatan nilai $\mathrm{pH}$ tanah pada perlakuan setelah musim pertama tidak merubah kategori tanah yaitu agak masam. Hal ini juga terjadi pada penelitian Purnamasari (2013) hasil analisis tanah awal menunjukkan $\mathrm{pH}$ tanah 5.00 sehingga dikategorikan sebagai tanah masam. Setelah dilakukannya penelitian tidak terlihat perubahan pada sifat tanah. Sifat tanah masih tergolong masam dengan kisaran nilai $\mathrm{pH}$ 5.00 - 5.40. Begitu juga pada musim tanam kedua tidak ada perubahan kategori $\mathrm{pH}$. Tetapi pada muslim kedua justru terjadi penurunan nilai $\mathrm{pH}$ pada perlakuan tanpa mulsa sebesar 0.5 , biomulsa A. pintoi 0.1 , sedangkan MPHP tidak terjadi perubahan.

C/N rasio. Terjadi perubahan $\mathrm{C} / \mathrm{N}$ rasio dengan nilai berkisar $0.5 \%$ kecuali pada perlakuan MPHP musim kedua terjadi perubahan $\mathrm{C} / \mathrm{N}$ ratio lebih dari $1 \%$. Semakin kecil nisbah $\mathrm{C} / \mathrm{N}$ menandakan nitrifikasi berjalan dengan baik yang artinya bahan organik semakin tersedia dan mudah diserap oleh tanaman. Menurut Sullivan (2012) jika nisbah C/N kurang dari 20\% maka zat hara akan terurai dengan cepat sementara jika lebih dari $25 \%$ akan terurai lebih lambat. Hal ini membuktikan hara tanah penelitian yang memiliki nisbah C/N 9.52 - 10.86 akan mudah terurai dan akan diserap dengan cepat oleh tanaman.

\section{Musim Tanam I Pengaruh Biomulsa pada Tanaman Oyong}

Hasil analisis sidik ragam menunjukkan perlakuan jenis mulsa berpengaruh sangat nyata terhadap tolok ukur pengamatan meliputi panjang tanaman, jumlah cabang, bobot brangkasan, bobot akar, bobot buah/tanaman, dan jumlah buah/tanaman. Tolok ukur lainnya berupa panjang buah dan bobot/buah tidak berpengaruh nyata (Tabel 2).

Secara umum morfologi buah oyong pada perlakuan tanpa mulsa memang lebih besar dibandingkan lainnya (Gambar 1). 
Tabel 2. Rekapitulasi analisis ragam pengaruh perlakuan jenis mulsa terhadap tolok ukur pengamatan tanaman oyong

\begin{tabular}{lcr}
\hline \multicolumn{1}{c}{ Tolok Ukur } & Jenis Mulsa $(\mathrm{M})$ & $\mathrm{KK}(\%)$ \\
\hline Panjang tanaman $(\mathrm{cm})^{\mathrm{Tr}}$ & $* *$ & 18.70 \\
Jumlah cabang $^{\mathrm{Tr}}$ & $* *$ & 20.80 \\
${\text { Bobot brangkasan }(\mathrm{g})^{\mathrm{Tr}}}^{\mathrm{Tr}}$ & $* *$ & 8.36 \\
${\text { Bobot akar }(\mathrm{g})^{\mathrm{Tr}}}^{* *}$ & 18.04 \\
Bobot buah/tanaman $(\mathrm{g})^{* *}$ & tn & 26.03 \\
Panjang buah $(\mathrm{cm})$ & $* *$ & 10.12 \\
Jumlah buah/tanaman & tn & 27.33 \\
Bobot/buah $(\mathrm{g})$ & 27.59 \\
\hline
\end{tabular}

Keterangan: **: berpengaruh sangat nyata pada taraf $1 \%$; *: berpengaruh sangat nyata pada taraf $5 \%$; tn: tidak berpengaruh nyata; KK: koefisien keragaman; Tr: hasil transormasi akar; KK: koefisien keragaman.

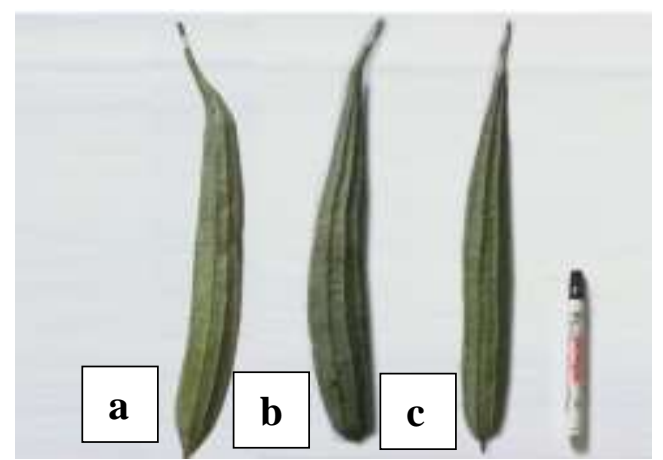

Gambar 1. Perbedaan morfologi buah tanaman oyong pada berbagai perlakuan mulsa (a) MPHP (b) tanpa mulsa (c) Biomulsa A. Pintoi

Kriteria panen menurut Puslitbanghorti (2013) yaitu buah berukuran maksimum, tidak terlalu tua, belum berserat, dan mudah dipatahkan.
Pada musim pertama Biomulsa A. pintoi belum mampu memperbaiki kandungan nitrogen tanah. Jumin (2008) menyatakan tanaman legum tetap membutuhkan nitrogen dan dipergunakan pada fase pertumbuhan awal menjelang terbentuknya bintil akar.

\section{Pertumbuhan Vegetatif Tanaman Oyong}

Pengamatan dilapang menunjukan pertumbuhan vegetatif yang lambat pada perlakuan biomulsa $A$. pintoi, beberapa tumbuh sangat kerdil hal ini yang menyebabkan nilai pertumbuhan vegetatif oyong perlakuan biomulsa A. pintoi bernilai paling rendah dari perlakuan lainnya. Komponen pengamatan panjang tanaman, jumlah cabang, bobot brangkasan pada perlakuan MPHP memiliki nilai paling tinggi tidak berbeda nyata dengan perlakuan tanpa mulsa dan berbeda sangat nyata dengan biomulsa $A$. pintoi. Tolok ukur lainnya berupa bobot akar pada perlakuan biomulsa $A$. pintoi tidak berbeda nyata dengan perlakuan tanpa mulsa, sedangkan perlakuan MPHP memiliki nilai yang paling tinggi (Tabel $3)$.

Pertumbuhan vegetatif yang rendah diduga karena pengaruh kompetisi dengan gulma dan A. pintoi. Hal ini sesuai penelitian Puspita (2014) yang menunjukan perlakuan biomulsa $A$. pintoi memiliki nilai paling besar pada bobot kering gulma. Selain gulma pada perlakuan biomulsa $A$. pintoi terjadi kompetisi tanaman oyong dengan $A$. pintoi dalam pengembilan hara sehingga pertumbuhan oyong tertekan karena jumlah tanaman $A$. pintoi yang banyak.

Tabel 3. Pengaruh perlakuan jenis mulsa terhadap pertumbuhan tanaman oyong

\begin{tabular}{|c|c|c|c|c|c|c|c|}
\hline \multirow{2}{*}{$\begin{array}{l}\text { Perlakuan } \\
\text { Jenis mulsa }\end{array}$} & \multirow[t]{2}{*}{$\begin{array}{l}\text { Panjang tanaman } \\
(\mathrm{cm})\end{array}$} & \multicolumn{2}{|c|}{ Jumlah cabang } & \multicolumn{2}{|c|}{$\begin{array}{c}\text { Bobot } \\
\text { brangkasan }(\mathrm{g})\end{array}$} & \multicolumn{2}{|c|}{ Bobot akar (g) } \\
\hline & & & & & & & \\
\hline MPHP (A) & $495.33 a$ & $18.20 \mathrm{a}$ & $4.21 \mathrm{a}$ & $658.00 \mathrm{a}$ & $25.05 \mathrm{a}$ & $18.13 \mathrm{a}$ & $4.21 \mathrm{a}$ \\
\hline Tanpa mulsa (B) & $432.60 \mathrm{a}$ & $16.13 \mathrm{a}$ & $4.00 \mathrm{a}$ & $521.00 \mathrm{a}$ & $22.63 a$ & $10.07 \mathrm{~b}$ & $3.22 b$ \\
\hline A. pintoi $(\mathrm{C})$ & $312.27 b$ & $10.00 \mathrm{~b}$ & $3.21 \mathrm{~b}$ & $361.60 \mathrm{~b}$ & $18.91 b$ & $9.47 b$ & $3.13 b$ \\
\hline Anova & $* *$ & $* *$ & $* *$ & ** & $* *$ & $* *$ & ** \\
\hline KK & 18.70 & 43.72 & $20.80^{\operatorname{Tr}}$ & 36.89 & $8.36^{\mathrm{Tr}}$ & 40.70 & $18.04^{\mathrm{Tr}}$ \\
\hline
\end{tabular}

\section{Produksi Tanaman Oyong}

Pelakuan MPHP pada komponen pengamatan bobot buah/tanaman dan jumlah buah/tanaman memiliki nilai paling tinggi berbeda sangat nyata dengan perlakuan tanpa mulsa, sedangkan perlakuan biomulsa $A$. pintoi memiliki nilai paling rendah berbeda sangat nyata dengan perlakuan tanpa mulsa. Komponen produksi panjang buah dan bobot/buah tidak berbeda nyata pada masing-masing perlakuan, namun dengan nilai paling tinggi pada perlakuan MPHP, kemudian perlakuan tanpa mulsa, sedangkan perlakuan biomulsa $A$. pintoi memiliki nilai paling rendah (Tabel 4). 
Tabel 4. Pengaruh perlakuan jenis mulsa terhadap produksi tanaman oyong

\begin{tabular}{lcccc}
\hline Perlakuan & $\begin{array}{c}\text { Bobot buah/ } \\
\text { tanaman }(\mathrm{g})\end{array}$ & $\begin{array}{c}\text { Panjang } \\
\text { buah } \\
(\mathrm{cm})\end{array}$ & $\begin{array}{c}\text { Jumlah } \\
\text { buah/ } \\
\text { tanaman }\end{array}$ & $\begin{array}{c}\text { Bobot/ } \\
\text { buah }(\mathrm{g})\end{array}$ \\
\hline Jenis mulsa & & & & \\
MPHP & $2305.60 \mathrm{a}$ & 40.26 & $9.80 \mathrm{a}$ & 237.02 \\
Tanpa mulsa & $1519.87 \mathrm{~b}$ & 39.46 & $6.60 \mathrm{~b}$ & 247.00 \\
A. pintoi & $970.13 \mathrm{c}$ & 37.98 & $4.27 \mathrm{c}$ & 228.40 \\
Anova & $* *$ & tn & $* *$ & tn \\
KK $(\%)$ & 26.03 & 10.12 & 27.33 & 27.59 \\
\hline
\end{tabular}

Keterangan: Angka-angka yang diikuti huruf yang sama pada kolom yang sama menunjukkan hasil yang tidak berbeda nyata berdasarkan uji DMRT pada taraf $\alpha=5 \%$; MPHP: mulsa plastik hitam perak; tn: tidak berpengaruh nyata; **: berpengaruh sangat nyata pada taraf $1 \%$; KK: koefisien keragaman.

\section{Musim Tanam II Pengaruh Biomulsa pada Tanaman Pakcoy}

Pengamatan perumbuhan dan produksi meliputi tinggi tanaman tiap minggu, jumlah daun tiap minggu, bobot akar/tanaman, dan bobot panen/tanaman. Hasil analisis sidik ragam menunjukkan perlakuan jenis mulsa berpengaruh sangat nyata pada tolok ukur tinggi tanaman pada minggu pertama sampai panen dan pada tolok ukur jumlah daun pada minggu kedua dan keempat, bobot panen/tanaman dan bobot akar/tanaman. Tolok ukur jumlah daun minggu pertama tidak berpengaruh nyata sedangkan jumlah daun pada minggu ketiga terlihat pengaruh nyata perlakuan mulsa (Tabel 5).

Tabel 5. Rekapitulasi analisis ragam pengaruh perlakuan jenis mulsa terhadap tolok ukur pengamatan tanaman pakcoy

\begin{tabular}{|c|c|c|}
\hline Tolok Ukur & Jenis Mulsa & KK \% \\
\hline \multicolumn{3}{|l|}{ Tinggi tanaman $(\mathrm{cm})$} \\
\hline Minggu 1 & $* *$ & 19.25 \\
\hline Minggu 2 & $* *$ & 17.19 \\
\hline Minggu 3 & $* *$ & 20.12 \\
\hline Minggu 4 & $* *$ & 14.45 \\
\hline \multicolumn{3}{|l|}{ Jumlah daun (helai) } \\
\hline Minggu 1 & tn & 12.20 \\
\hline Minggu 2 & $* *$ & 16.74 \\
\hline Minggu 3 & $*$ & 23.49 \\
\hline Minggu 4 & $* *$ & 20.10 \\
\hline Bobot panen/tanaman $(\mathrm{g})^{\operatorname{Tr}}$ & $* *$ & 20.54 \\
\hline Bobot akar/tanaman $(\mathrm{g})^{\operatorname{Tr}}$ & $* *$ & 29.96 \\
\hline
\end{tabular}

Pertumbuhan Vegetatif Tanaman Pakcoy

Perlakuan mulsa terhadap pengamatan tinggi tanaman minggu pertama dan kedua terlihat pengaruh sangat nyata dengan perlakuan tanpa mulsa memiliki nilai terendah dan perlakuan MPHP memiliki nilai paling tinggi tidak berbeda nyata dengan perlakuan biomulsa $A$. pintoi. Sedangkan pada minggu ketiga dan keempat tinggi tanaman pada perlakuan tanpa mulsa tidak berbeda nyata dengan perlakuan biomulsa $A$. pintoi, sedangkan perlakuan MPHP memiliki nilai yang paling tinggi berbeda nyata dengan perlakuan lainya (Tabel 6).

Perlakuan mulsa $A$. pintoi terhadap tinggi tanaman memiliki nilai lebih tinggi dari perlakuan tanpa mulsa pada minggu pertama dan kedua diduga karena adanya kompetisi antara tanaman dan A. pintoi. Menurut Kurniawan 2012 intensitas cahaya sebagai salah satu faktor pertumbuhan sangat dipengaruhi oleh kompetisi. Perlakuan intensitas cahaya yang diturunkan biasanya diikuti dengan penurunan jumlah cabang tanaman. Hal ini dikarenakan dengan intensitas cahaya rendah, tanaman tumbuh tinggi, sehingga hasil fotosintesis yang digunakan untuk pembentukan cabang sedikit, akibatnya jumlah cabang sedikit. Peningkatan intensitas cahaya meningkatkan proses fotosintesis pada tanaman, karena cahaya matahari merupakan sumber energi bagi fotosintesi. Sedangkan pada perlakuan MPHP tanaman lebih tinggi dari perlakuan lain diduga karena jumlah ion terlarut yang tinggi berdasarkan nilai EC perlakuan MPHP.

Perlakuan mulsa terhadap jumlah daun pada minggu pertama tidak berbeda nyata. Sedangkan perlakuan mulsa terhadap jumlah daun pada minggu kedua dan keempat terdapat pengaruh sangat nyata. Perlakuan mulsa pada minggu ketiga terdapat pengaruh nyata terhadap jumlah daun pada masing-masing perlakuan. Perlakuan MPHP memiliki nilai paling tinggi dan perlakuan biomulsa $A$. pintoi memiliki nilai paling rendah tidak berbeda nyata dengan perlakuan tanpa mulsa (Tabel 6).

\section{Produksi Tanaman Pakcoy}

Hasil analisis sidik ragam menunjukkan perlakuan mulsa berbeda sangat nyata pada tolok ukur bobot akar/tanaman dan bobot panen/tanaman. Komponen produksi bobot akar/tanaman dan bobot panen/tanaman perlakuan MPHP memiliki nilai paling tinggi berbeda sangat nyata dengan perlakuan tanpa mulsa dan biomulsa A. pintoi (Tabel 7). Hal ini seperti pada penelitian Baharuddin (2010) yang menyatakan rata-rata bobot panen tertinggi diperoleh pada perlakuan mulsa plastik hitam perak (106.39 g), berbeda nyata dengan tanpa mulsa (35.19 g) dan seluruh perlakuan biomulsa. 
Tabel 6. Pengaruh perlakuan jenis mulsa terhadap tinggi dan jumlah daun tanaman pakcoy

\begin{tabular}{|c|c|c|c|c|c|c|c|c|}
\hline \multirow{3}{*}{ Perlakuan } & \multicolumn{4}{|c|}{ Tinggi tanaman $(\mathrm{cm})$} & \multicolumn{4}{|c|}{ Jumlah daun (helai) } \\
\hline & \multicolumn{8}{|c|}{ Minggu } \\
\hline & 1 & 2 & 3 & 4 & 1 & 2 & 3 & 4 \\
\hline \multicolumn{9}{|l|}{ Jenis mulsa } \\
\hline MPHP & $9.22 \mathrm{a}$ & $11.37 \mathrm{a}$ & $15.26 \mathrm{a}$ & $19.05 \mathrm{a}$ & 4.80 & $6.27 \mathrm{a}$ & $8.07 \mathrm{a}$ & $11.73 \mathrm{a}$ \\
\hline tanpa mulsa & $6.91 b$ & $7.97 \mathrm{~b}$ & $10.20 \mathrm{~b}$ & $14.60 \mathrm{~b}$ & 4.53 & $4.47 b$ & $5.40 \mathrm{~b}$ & $7.73 b$ \\
\hline A. pintoi & $9.51 \mathrm{a}$ & $10.45 \mathrm{a}$ & $11.47 \mathrm{~b}$ & $14.17 \mathrm{~b}$ & 4.13 & $4.73 b$ & $6.13 b$ & $6.33 b$ \\
\hline Anova & $* *$ & $* *$ & $* *$ & ** & tn & $* *$ & $*$ & $* *$ \\
\hline KK & 19.25 & 17.19 & 20.12 & 14.45 & 12.20 & 16.74 & 23.49 & 20.10 \\
\hline
\end{tabular}

Keterangan: Angka-angka yang diikuti huruf yang sama pada kolom yang sama menunjukkan hasil yang tidak berbeda nyata berdasarkan uji DMRT pada taraf $\alpha=5 \%$; MPHP: mulsa plastik hitam perak; **: berpengaruh sangat nyata pada taraf $1 \%$; KK: koefisien keragaman.

Tabel 7. Pengaruh perlakuan jenis mulsa terhadap produksi tanaman pakcoy

\begin{tabular}{lcccc}
\hline Perlakuan & \multicolumn{2}{c}{$\begin{array}{c}\text { Bobot } \\
\text { akar/tanaman }\end{array}$} & \multicolumn{2}{c}{$\begin{array}{c}\text { Bobot } \\
\text { panen/tanaman }\end{array}$} \\
\hline Jenis mulsa & & & & \\
MPHP & $1.85 \mathrm{a}$ & $1.85 \mathrm{a}$ & $7.50 \mathrm{a}$ & $7.50 \mathrm{a}$ \\
Tanpa mulsa & $1.22 \mathrm{~b}$ & $1.22 \mathrm{~b}$ & $3.83 \mathrm{~b}$ & $3.83 \mathrm{~b}$ \\
A. pintoi & $1.22 \mathrm{~b}$ & $1.22 \mathrm{~b}$ & $3.18 \mathrm{~b}$ & $3.18 \mathrm{~b}$ \\
Anova & $* *$ & $* *$ & $* *$ & $* *$ \\
KK $(\%)$ & 65.77 & $20.54^{\operatorname{Tr}}$ & 81.67 & $29.96^{\operatorname{Tr}}$ \\
\hline
\end{tabular}

Keterangan: Angka-angka yang diikuti huruf yang sama pada kolom yang sama menunjukkan hasil yang tidak berbeda nyata berdasarkan uji DMRT pada taraf $\alpha=5 \%$; MPHP: mulsa plastik hitam perak; **: berpengaruh sangat nyata pada taraf $1 \%$; Tr: data transformasi akar; KK: koefisien keragaman.

Pengamatan morfologi memperlihatkan perbedaan yang jelas pada hasil produksi pakcoy (Gambar 2). Perlakuan MPHP memiliki nilai paling tinggi berbeda nyata dari perlakuan lainnya. Hal ini diduga karena perlakuan MPHP lebih efektif dalam menghambat pertumbuhan gulma. Sesuai penelitian Puspita (2014) menyatakan MPHP relatif lebih efektif menekan pertumbuhan gulma terhadap bobot kering gulma total dibandingkan dengan perlakuan tanpa mulsa maupun biomulsa A. pintoi. Menurut Baharuddin (2010) perlakuan biomulsa A. pintoi belum mampu menekan gulma secara efektif. Hal ini diduga karena $A$. pintoi memberikan kondisi tanah yang lebih lembab untuk menyimpan air sehingga memberikan peluang gulma yang memiliki daya tumbuh yang tinggi dapat tumbuh lebih baik dan menekan pertumbuhan pakcoy dalam kompetisinya memperoleh hara.

Pemeliharaan sekitar tanaman utama tidak intensif akibatnya tanaman $A$. pintoi tumbuh rapat dengan tanaman utama dan berkompetisi. Biomulsa A. pintoi jauh lebih banyak sehingga menekan produksi pakcoy (Gambar 3). Kompetisi ini nampak dari hasil komponen bobot panen/tanaman maupun bobot akar/tanaman pada perlakuan biomulsa $A$. pintoi memiliki nilai yang paling rendah. Rhizom A. pintoi sampai kedalam $20 \mathrm{~cm}$ (Mannetje 2007) sama dengan perakaran pakcoy, sehingga terjadi kompetisi dalam solum tanah yang sama yang menyebabkan tanaman utama tidak tumbuh baik. Menurut Akiefnawati 1995 pengetahuan akan distribusi dan kedalaman akar ini sangat diperlukan bila petani ingin mengkombinasikan pohon dengan tanaman semusim di lahannya. Potensi terbesar terjadinya persaingan dalam menyerap air dan hara adalah pada lapisan tanah atas pada zona antara $20-80$ $\mathrm{cm}$ dari batang.

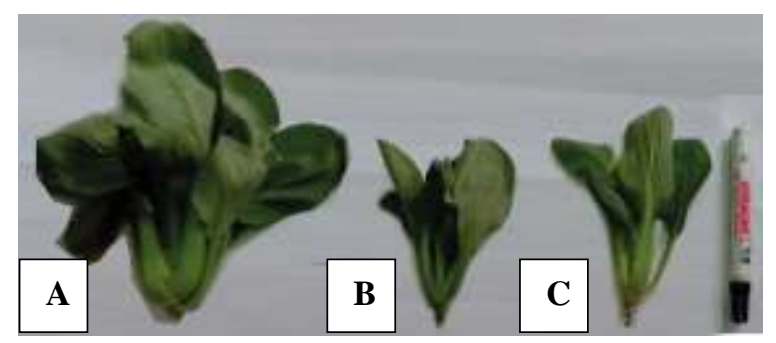

Gambar 2. Perbedaan morfologi panen tanaman pakcoy pada perlakuan mulsa (a) MPHP (b) tanpa mulsa (c) Biomulsa A. pintoi

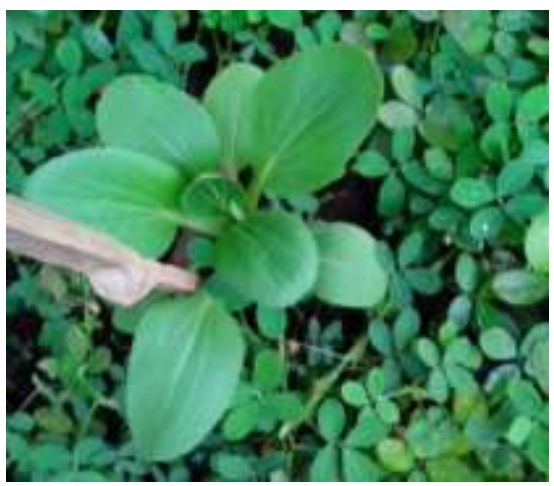

Gambar 3. Pengamatan pertumbuhan pakcoy pada perlakuan biomulsa A. pintoi pada 3 MST 


\section{KESIMPULAN}

Penggunaan biomulsa $A$. pintoi setelah dua musim tanam menunjukan penurunan nilai $\mathrm{C}$ organik yang paling kecil dibandingkan perlakuan lain. Biomulsa $A$. pintoi dalam jangka panjang diharapkan dapat memperbaiki kualitas tanah dengan penambahan kandungan C-organik. Perlakuan MPHP pada tanaman oyong meningkatkan pertumbuhan vegetatif yaitu pada parameter panjang tanaman, jumlah cabang dan bobot brangkasan dengan respon yang sama dengan perlakuan tanpa mulsa, sedangkan pada parameter bobot akar perlakuan MPHP memiliki nilai paling tinggi dari perlakuan lainnya. Perlakuan mulsa plastik hitam perak terhadap komponen produksi buah/tanaman dan jumlah buah/tanaman memiliki respon yang paling baik dibandingkan perlakuan lainnya. Perlakuan mulsa memiliki respon yang sama terhadap panjang buah dan bobot/buah. Perlakuan MPHP memiliki respon yang sama dengan perlakuan biomulsa $A$. pintoi pada tanaman pakcoy terhadap tinggi tanaman minggu pertama dan kedua. Secara umum perlakuan MPHP memiliki nilai terbaik dibandingkan dengan perlakuan tanpa mulsa dan biomulsa $A$. pintoi terhadap tinggi tanaman, jumlah daun, bobot akar, dan bobot panen.

\section{DAFTAR PUSTAKA}

Alfian, M. 1997. Pengaruh taraf bahan organik dan masa inkubasi terhadap kandungan $\mathrm{C}$ organik, $\mathrm{N}$-total, $\mathrm{NH}_{4}{ }^{+}, \mathrm{NO}_{3}^{-}$, dan $\mathrm{C} / \mathrm{N}$ tanah latosol Dramaga. Skripsi. Institut Pertanian Bogor, Bogor.

Akiefnawati, R. 1995. Pengaruh naungan, kompetisi serapan air, dan hara tanaman pagar terhadap pertumbuhan dan produksi jagung pada ultisol daerah Lampung Utara. Tesis. Universitas Brawijaya, Malang.

Armiadi. 2009. Penambatan Nitrogen secara Biologis pada Tanaman Leguminosa. Wartazoa. Vol. 19(1)

Baharuddin, R. 2010. Penggunaan kacang hias (Arachis pintoi) sebagai biomulsa pada budidaya tanaman tomat (Lycopersicon esculentum M.). Skripsi. Institut Pertanian Bogor, Bogor.
[Balittan] Balai Penelitian Tanah. 2004. Kacang Hias (Arachis pintoi) Pada Usaha Tani Lahan Kering. Pusat Litbang Tanah dan Agroklimat, Bogor.

[BMKG] Badan Meteriologi Klimatologi dan Geofisia. 2014. Klasifikasi Iklim [internet]. [diunduh 2014 Jun 6]. Tersedia pada : http://lasiana.ntt.bmkg.go.id/ pustaka/klasifikasi-iklim.

Boerhendhy, L., Sianturi, M. 1986. Membangun Penutup Tanah Kacangan di Areal Perkebunan Karet. Balai Penelitian Sembawa, Sembawa. 36 hal.

[Deptan] Departemen Pertanian. 2013. Petunjuk umum program peningkatan produksi, produktivitas dan mutu produk hortikultura berkelanjutan tahun 2013 [internet]. [diunduh 2013 Oktober 18]. Tersedia pada: http://www.deptan.go.id/... pedum_HORTI.pdf.

Effendi, H. 2003. Telaah Kualitas Air Bagi Pengelolaan Sumber Daya dan Lingkungan Perairan. Kanisius, Jakarta.

Jumin, H. B. 2008. Dasar-Dasar Agronomi Edisi Revisi. PT Raja Grafindo, Jakarta.

Kartika, J, G., Reyes, M, R., Susila, A, D. 2009. Review of Literature on Perennial Peanut (Arachis pintoi) as Potential Cover Crop in the Tropics. Di dalam: Susila AD et al., editor. Kumpulan Makalah Seminar Ilmiah Perhorti (2009). Perhimpunan Hortikultura Indonesia, Bogor. hal 391399.

Kartasaputra, G., Sutedjo, M, M. 2000. Teknologi Konservasi Tanah dan Air. PT Rineka Cipta, Jakarta.

Kurniawan, H. 2012. Strata Tajuk dan Kompetisi Pertumbuhan Cendana (Santalum album Linn.) di Pulau Timor. J. Penelitian Kehutanan Wallace. Vol.1 (2):hal 9

Mannetje, L. 2007. Arachis pintoi Krap. \& Greg [internet]. [diunduh 2014 Mei 20]. Tersedia pada http://www.betuco.be/coverfodder/Arachi s\%pintoi.pdf 
McNeill, A, M,. Zhu ,C., Fillery, I, R, P. 1997. Use of in situ ${ }^{15} \mathrm{~N}$-labelling to estimate the total below ground nitrogen of pasture legumes in intact soil-plant systems. Australia(AU): Australian Journal of Agricultural Research.48.hal 295-304

Purnamasari, P. 2013. Pengaruh jarak tanam dan konsentrasi Rootone-F terhadap kecepatan penutupan biomulsa Arachis pintoi krap. \& greg. Pada pertanaman cabai (Capsicum annuиm L.) Keriting hibrida. Skripsi. Institut Pertanian Bogor, Bogor.
[Puslitbanghorti] Pusat Penelitian dan Pengembangan Hortikultura. 2013. Budidaya Tanaman Oyong. Deptan, Jakarta.

Puspita, G. R. 2014. Interaksi jenis biomulsa dan jarak tanam kailan terhadap produksi tanaman kailan (Brassica oleracea L. cv. grup Kailan). Skripsi. Institut Pertanian Bogor, Bogor.

Sullivan, C. 2012. Reduced Tillage in Organic Cropping Systems on The Canadian Prairies. Tesis. University of Saskatchewan, Saskatoon. 